\title{
Effects of Nitrogen and Phosphate Biofertilizers on Morphological and Agronomic Characteristics of Sesame (Sesamum indicum L.)
}

\author{
Ali Nasrollahzadeh Asl \\ Department of Agronomy, College of Agriculture, Khoy Science and Research Branch, Islamic Azad University, \\ Khoy, Iran \\ Email: ali_nasr462@yahoo.com
}

How to cite this paper: Asl, A.N. (2017) Effects of Nitrogen and Phosphate Biofertilizers on Morphological and Agronomic Characteristics of Sesame (Sesamum indicum L.). Open Journal of Ecology, 7, 101111. https://doi.org/10.4236/oje.2017.72008

Received: November 7, 2016

Accepted: January 31, 2017

Published: February 3, 2017

Copyright $\odot 2017$ by author and Scientific Research Publishing Inc. This work is licensed under the Creative Commons Attribution International License (CC BY 4.0).

http://creativecommons.org/licenses/by/4.0/

\section{c) (i) Open Access}

\begin{abstract}
In order to investigate the effects of Barvar-2 phosphate biofertilizer and nitroxin biofertilizers on agronomical characteristics of sesame, an experiment was carried out as factorial based on randomized complete block design with three replications and two factors in Khoy city, northwest of Iran, in 2014 growing seasons. The factors were as follows: phosphorus fertilizer in three levels (control, barvar-2 phosphate bio-fertilizer with $100 \mathrm{~kg}$ triple superphosphate per hectare and $200 \mathrm{~kg}$ triple superphosphate per hectare) and nitrogen fertilizer in four levels (control, nitroxin bio-fertilizer with urea at rate of $100 \mathrm{~kg} \cdot \mathrm{ha}^{-1}$, nitroxin biofertilizer with urea at rate of $150 \mathrm{~kg} \cdot \mathrm{ha}^{-1}$ and urea at rate of $\left.200 \mathrm{~kg} \cdot \mathrm{ha}^{-1}\right)$. The results showed that a significant effect of nitrogen and phosphate biofertilizer, on plant height, branches per plant, pods per plant, seed in pod, oil percent, seed yield and harvest index. Maximum seed yield of 1274.37 and $1232.5 \mathrm{~kg} \cdot \mathrm{ha}^{-1}$ was obtained from treatments of 200 $\mathrm{kg} \cdot \mathrm{ha}^{-1}$ triple superphosphate and barvar-2 phosphate biofertilizer besides 100 $\mathrm{kg} \cdot \mathrm{ha}^{-1}$ triple superphosphate. For nitrogen biofertilizer, maximum seed yield of 1264.83 and $1246.12 \mathrm{~kg} \cdot \mathrm{ha}^{-1}$ was obtained from treatments of $200 \mathrm{~kg} \cdot \mathrm{ha}^{-1}$ urea and nitroxin biofertilizer besides urea $150 \mathrm{~kg} \cdot \mathrm{ha}^{-1}$ respectively. According to the results of this experiment, consumption of chemical fertilizer of triple super phosphate was reduced equal to $50 \%$ using Barvar-2 phosphate biofertilizer and consumption of chemical fertilizer of urea was reduced equal to $25 \%$ using nitroxin biofertilizer.
\end{abstract}

\section{Keywords}

Seed Yield Components, Fertilizer, Sesame, Harvest Index 


\section{Introduction}

Sesame is a yearling plant and one of the oldest oilseed plants that is compatible with hot and semi-hot areas and consists of a high-percent oil (45\%) and protein (19\% - 25\%) [1]. Today, one of the main bases in sustainable agriculture is application of biologic fertilizers in agronomical ecosystems to reduce consumption of chemical inputs so that they can guarantee production sustainability of agriculture systems in some cases as a substitution and as a supplement in majority of cases for chemical fertilizers [2]. Biologic fertilizers consist of some beneficial microorganisms that are produced for specific purposes such as nitrogen fixation, and releasing phosphate, potassium, and iron ions. These microorganisms usually are placed around the root helping the plant to nutrient uptake through cohabitation [3]. These bacteria have more than one role so that they not only help to uptake a specific element but also can absorb other elements, reduce illnesses, improve soil structure, more promote plant growth, increase quantity and quality of product and increase plant tolerance against environmental stresses [4]. [5] expressed that application of biologic fertilizers with a low percent of chemical fertilizers on sesame significantly increased plant height, seed yield, and oil. [6] stated that use of a combination of growth promoting bacteria (nitroxin and phosphorus) with nitrogen in addition to reduction in use of chemical fertilizers led to increase in nitrogen and phosphorus in sunflower seed compared to treatment without using bacteria. [7] reported that application of biologic fertilizers on sesame significantly increased plant height, branches per plant, pods per plant, weight of one thousand seeds, and seed yield. [8] has reported that biofertilizer can significantly improve yield and yield components of fennel. [9] reported that integrated application of biological and chemical nitrogen fertilizer would increase yield and yield components of canola compared to control treatment (treated plants with nitroxin without using chemical nitrogen fertilizer). Hence, it seems that efficiency of biological fertilizers will increase at the presence of chemical fertilizer.

This study was conducted to investigate the effect of biological nitroxin, Barvar-2 phosphate fertilizers on increase in seed yield, and sesame oil in weather conditions of Khoy Province.

\section{Materials and Methods}

This study was carried out in spring, 2014 in a farm located at $2 \mathrm{~km}$ distance of south west of Khoy city, northwest of Iran, in 2014 growing seasons. The height of this area from sea level is equal to 1175 meters with geographical characteristics of eastern $44^{\circ}$ and $23^{\prime}$ and northern $38^{\circ}$ and $18^{\prime}$. The place soil was tested and recognized as loamy soil with $\mathrm{pH}$ about 7/6 (Table 1). The research was conducted through two-factor factorial experiment in frame of Randomized Complete Blocks with 3 replications. The factors were as follows: first factor was phosphorus fertilizer at three levels (control, Barvar-2 phosphate biofertilizer with $100 \mathrm{~kg}$ chemical fertilizer of triple super-phosphate per hectare, $200 \mathrm{~kg}$ chemical fertilizer of triple super-phosphate per hectare) and second factor was 
Table 1. Physical and chemical characteristics of soil.

\begin{tabular}{cccccccccc}
\hline $\begin{array}{c}\text { EC } \\
(\mathrm{ds} / \mathrm{m})\end{array}$ & $\begin{array}{c}\text { Soil } \\
\text { texture }\end{array}$ & $\begin{array}{c}\text { Silt } \\
(\%)\end{array}$ & $\begin{array}{c}\text { Clay } \\
(\%)\end{array}$ & $\begin{array}{c}\text { Sand } \\
(\%)\end{array}$ & $\begin{array}{c}\text { OC } \\
(\%)\end{array}$ & $\begin{array}{c}\mathbf{N} \\
(\%)\end{array}$ & $\begin{array}{c}\mathbf{P} \\
(\mathrm{ppm})\end{array}$ & $\begin{array}{c}\mathrm{K} \\
(\mathrm{ppm})\end{array}$ & $(\mathrm{pH})$ \\
\hline $0 / 6$ & loam & 49 & 19 & 32 & $0 / 89$ & $0 / 08$ & $8 / 6$ & $413 / 8$ & $7 / 6$ \\
\hline
\end{tabular}

nitrogen at 4 levels (control, nitroxin biofertilizer with $100 \mathrm{~kg}$ chemical fertilizer of urea per hectare, nitroxin biofertilizer with $15 \mathrm{~kg}$ chemical fertilizer of urea per hectare, $200 \mathrm{~kg}$ chemical fertilizer of urea per hectare). Cultivation operations were conducted on May 15th, 2014. There are 108 Azospirillum and Azotobacter per $\mathrm{ml}$ of nitroxin. The bacteria in nitroxin biofertilizer can develop balanced shoots and roots of plant by a growth promoting hormone, like Auxin, and amino acid, this biofertilizer was produced by Mehr Asia Biotechnology Company in Iran [10]. The Barvar-2 phosphate biofertilizer used for this experiment was supplied by Green Biotechnology Company in Iran; PhosphateEBarvar2 consisted of two kinds of phosphate solubilizing bacteria, Pseudomonas putida (strain p13) and Bacillus lentus (strain p5). Pseudomonas putida by producing of organic acids caused released of the phosphates from inorganic compounds whereas Bacillus lentus by producing of phosphatase enzyme causes release of the phosphate from organic compounds (Raissi et al., 2012). Each experimental plot included 4 cultivation rows with 4 meters in length and $50 \mathrm{~cm}$ distances in row and distance between plans in each row was $10 \mathrm{~cm}$. the seeds were planted at $2-3 \mathrm{c}$ depth through dry soil with density of 20 plants per $\mathrm{m}^{2}$.

Different amounts of triple superphosphate chemical fertilizer was added to soil before cultivation based on experimental treatment and different amounts of chemical fertilizer of urea was added to experimental plot within two stages before cultivation based on experimental treatment at the time of flowering while Potassium Fertilizer was not used due to high amount of potassium in soil. 1-liter Nitroxin biofertilizer was consumed as seed treatment per hectare and to apply Barvar-2 phosphate biofertilizer, $100 \mathrm{~g}$ of this biofertilizer per hectare was first solved in a 10-liter water then the sesame seeds were placed in water containers for 10 minutes before cultivation and stained with fertilizing solution (as seed treatment) and then were planted. Irrigation was done though submerging one every 10 days based on region tradition and green aphid pest was once destroyed during growth season using Confidor Toxin with a half in thousand concentration and weeds were pruned manually. In this study, plant height traits, number of branches in plant, weight of one thousand seeds, the number of pods per plant, the number of seeds per pod, seed yield, seed oil percent, and harvest index were measured. Two side rows and half of meter of the beginning and end of the middle row were eliminated for sampling due to marginal effects. To determine plant height traits, number of branches in plant, number of pods in plant and number of seeds in pod, 8 plants from each experimental Crete were randomly chosen and their average was recorded as the mentioned traits. Yield seed was calculated at a level equal to $2 \mathrm{~m}^{2}$ after drying and reaching the seeds moisture to 13 - 14 percent. Then data were analyzed by MSTATC soft- 
ware and means compared with Duncan's Multiple Range Test at 5\% probability level.

\section{Results and Discussion}

\subsection{Plant Height}

The effect of phosphor on plant height was significant at $1 \%$ prob level (Table 2). Treatments including complete use of triple superphosphate chemical fertilizer and Barvar-2 phosphate biological fertilizer with $100 \mathrm{~kg}$ triple superphosphate chemical fertilizer per hectare assigned into a same statistical group in terms of plant height and indicated the highest plant height (Table 3). This matter is because of the beneficial role of phosphorus and biological fertilizers in fertility of soil and improvement of plant root as well as plant growth. [11] [12] declared after some experiments that solubilizing bacteria of phosphate not only solve dissolved phosphates of soil by synthesis of growth promoting hormones such as indole acetic acid and gibberellins but also increase product growth. [13] conducted an experiment on sunflower in which, the highest plant height was related to integrated treatments of phosphorus chemical and biological fertilizer. [14] indicated in an experiment on fennel plant that use of biological phosphate fertilizer had a significant effect on plant height. Plant height was affected by nitrogen fertilizer at probability level of $1 \%$ (Table 2). The highest plant height was respectively observed through use of pure urea and $150 \mathrm{~kg}$ per hectare urea with nitroxin and the lowest seed yield was observed in control mood (Table 3 ). Regarding the effect of biological fertilizers on increase in plant height, it can be stated that this matter is possibly caused by increase in nitrogen nutrient uptake and its effect on improvement of photosynthesis and increase in plant growth as a result. Vegetative characteristics of plants such as plant height are strongly affected by nutrients and water. Enough water and nutrients (especially nitrogen) are effective in increase in plant height through affecting cells' division and enlargement [15]. [16] expressed that application of biological fertilizers with a low percent of nitrogen chemical fertilizers significantly increases plant height and seed yield of sesame. [17] have stated that nitrogen chemical and biological fertilizers have significantly increased plant height of medicinal plant of cumin.

Table 2. Analysis of variance effects of phosphate and nitrogen biofertilizers on different traits of sesame.

\begin{tabular}{|c|c|c|c|c|c|c|c|c|c|}
\hline \multirow[b]{2}{*}{ S.O.V } & \multirow[b]{2}{*}{ df } & \multicolumn{8}{|c|}{ Means of squares } \\
\hline & & $\begin{array}{l}\text { Branches } \\
\text { in plant }\end{array}$ & $\begin{array}{l}\text { Plant } \\
\text { height }\end{array}$ & $\begin{array}{c}\text { Pods in } \\
\text { plant }\end{array}$ & $\begin{array}{c}\text { Seeds } \\
\text { per pod }\end{array}$ & $\begin{array}{c}100 \text { seeds } \\
\text { weight (gr) }\end{array}$ & Seed yield & Oil percent & HI \\
\hline Replication & 2 & $0 / 267$ & $132 / 92$ & $0 / 267$ & $9 / 29$ & $7 / 27$ & $2967 / 68$ & $1 / 02$ & $7 / 62$ \\
\hline Phosphate & 2 & $1 / 10^{*}$ & $598 / 38^{*}$ & $23 / 86^{*}$ & $81 / 17^{\star *}$ & $1 / 19$ & $59310 / 79^{* *}$ & $2 / 78^{\star *}$ & $42 / 95^{*}$ \\
\hline Nitrogen & 3 & $1 / 02^{\star}$ & $629 / 34^{\star *}$ & $45 / 67^{\star \star}$ & $124 / 29^{\star *}$ & $3 / 21$ & $38100 / 39^{* *}$ & $5 / 34^{\star *}$ & $48 / 82^{*}$ \\
\hline $\mathrm{N} \times \mathrm{P}$ & 6 & $0 / 107$ & $133 / 01$ & $1 / 51$ & $25 / 93$ & $2 / 72$ & $8840 / 19$ & $1 / 12$ & $3 / 85$ \\
\hline Error & 22 & $0 / 228$ & $46 / 5543$ & $5 / 09$ & $16 / 88$ & $3 / 85$ & $8780 / 36$ & $0 / 52$ & $14 / 49$ \\
\hline CV (\%) & & $10 / 34$ & $8 / 81$ & $13 / 89$ & $10 / 34$ & $6 / 74$ & $15 / 47$ & $2 / 79$ & $8 / 24$ \\
\hline
\end{tabular}

${ }^{*},{ }^{*}=$ Significant at $5 \%$ and $1 \%$, respective. 
Table 3. Comparison of mean effects of phosphate and nitrogen biofertilizers on different traits of sesame.

\begin{tabular}{|c|c|c|c|c|c|c|c|c|c|}
\hline \multicolumn{2}{|c|}{ Experimental factor } & $\begin{array}{l}\text { Plant height } \\
(\mathrm{cm})\end{array}$ & $\begin{array}{l}\text { Branches } \\
\text { in plant }\end{array}$ & $\begin{array}{l}\text { Pods in } \\
\text { plant }\end{array}$ & $\begin{array}{l}\text { Seeds in } \\
\text { pod }\end{array}$ & $\begin{array}{l}1000 \text { seed } \\
\text { weight }(\mathrm{gr})\end{array}$ & $\begin{array}{l}\text { Seed yield } \\
\left(\mathrm{kg} \cdot \mathrm{ha}^{-1}\right)\end{array}$ & $\begin{array}{l}\text { Oil percent } \\
\text { (\%) }\end{array}$ & HI \\
\hline \multirow{3}{*}{$\begin{array}{l}\text { Phosphate } \\
\text { fertilizer }\end{array}$} & $\begin{array}{l}\text { Control (lack of using } \\
\text { fertilizer) }\end{array}$ & $61 / 73 \mathrm{~b}$ & $3 / 89 \mathrm{~b}$ & $24 / 95 \mathrm{~b}$ & $21 / 09 b$ & $4 / 01$ & $904 / 29 b$ & $44 / 83 \mathrm{~b}$ & $31 / 96 \mathrm{~b}$ \\
\hline & $\begin{array}{c}\text { Biophosphate }+100 \\
\mathrm{~kg} / \mathrm{h}^{-1} \text { superphosphate }\end{array}$ & $66 / 59 \mathrm{ab}$ & $5 / 92 \mathrm{a}$ & $35 / 71$ a & $26 / 56 \mathrm{ab}$ & $4 / 06$ & $1286 / 5 \mathrm{a}$ & $45 / 65$ a & $33 / 2 \mathrm{a}$ \\
\hline & $\begin{array}{c}200 \mathrm{~kg} / \mathrm{h}^{-1} \\
\text { superphosphate }\end{array}$ & $70 / 09$ a & $6 / 07 a$ & $36 / 74$ a & $29 / 02 \mathrm{a}$ & $4 / 13$ & $1310 / 37$ a & $45 / 73$ a & $34 / 02 \mathrm{a}$ \\
\hline \multirow{4}{*}{$\begin{array}{l}\text { Nitrogen } \\
\text { fertilizer }\end{array}$} & $\begin{array}{l}\text { Control (lack of using } \\
\text { fertilizer) }\end{array}$ & $55 / 32 \mathrm{c}$ & $4 / 81 \mathrm{~b}$ & $23 / 05 c$ & $21 / 46 b$ & $3 / 06$ & $820 / 1 \mathrm{c}$ & $44 / 86 \mathrm{~b}$ & $31 / 02 \mathrm{c}$ \\
\hline & Nitroxin $+100 \mathrm{~kg}$ urea & $63 / 74 \mathrm{~b}$ & $5 / 24 \mathrm{ab}$ & $30 / 74 \mathrm{~b}$ & $23 / 52 \mathrm{~b}$ & $3 / 12$ & $1171 / 46 \mathrm{~b}$ & $46 / 32 \mathrm{a}$ & $32 / 73 \mathrm{~b}$ \\
\hline & Nitroxin $+150 \mathrm{~kg}$ urea & $71 / 62 \mathrm{a}$ & $5 / 52 \mathrm{a}$ & $37 / 73$ a & $28 / 04 \mathrm{a}$ & $3 / 18$ & $1317 / 12 \mathrm{a}$ & $45 / 84 \mathrm{ab}$ & $34 / 72 \mathrm{a}$ \\
\hline & $200 \mathrm{~kg}$ urea & $74 / 14 \mathrm{a}$ & $5 / 58 \mathrm{a}$ & $38 / 35 \mathrm{a}$ & $28 / 76 \mathrm{a}$ & $3 / 23$ & $1332 / 83 \mathrm{a}$ & $44 / 62 \mathrm{~b}$ & $33 / 76 \mathrm{ab}$ \\
\hline
\end{tabular}

Dissimilar letters in each column indicate significant differences at the $5 \%$ level.

\subsection{Number of Branches per Plant}

The effect of phosphorus fertilizer on number of branches per plant was significant at probability level of $5 \%$ (Table 2). The largest number of branches per plant was observed in treatments including $200 \mathrm{~kg}$ per hectare of triple super phosphate and biological phosphorus with $100 \mathrm{~kg}$ per hectare triple superphosphate (Table 3). Seemingly, bio-fertilizer strengths plant growth through increasing free phosphorus of soil so that more photosynthetic materials are produced in plant, the growth of vegetative buds is promoted and the number of branches in plant is increased. [18] declared that under the circumstances of phosphorus shortage, increase in activities of some hormones such as ethylene would prevent from growth of Falcaria vulgaris of plant and the activity of some hormones such as Cytokinin, that plays a vital role in cellular division and development in meristematic areas, will be reduced under such circumstances while the activity of such hormones is increased leading to improved plant organs' growth when phosphorus exists. [19] examined the effect of phosphorus and nitrogen biologic fertilizers on quantitative and qualitative traits of Echium Plant and concluded that the studied treatments had a significant effect on plant height, number of branches, yield of flowering shoot, percent and yield of Echium essence.

The effect of nitrogen fertilizer on number of branches per plant was significant at prob level of 5\% (Table 2). The largest number of branches per plant was respectively observed in consumption of $200 \mathrm{~kg}$ per hectare urea and $150 \mathrm{kh}$ per hectare urea with nitroxin and the lowest number of branches per plant was observed in control mood (Table 3). Nitrogen could promote vegetative growth of plant through increasing soil fertility so that the number of branches increased. [20] indicated that biological fertilizers with nitrogen fixator bacteria help the plant to uptake more nutrients so that Arial organs are grown and side branches of plan are increased.

[21] expressed that nitrogen fertilizers have significant effect on number of 
branches and the largest number of branches in sesame plant was observed in integrated application of 50\% chemical fertilizer + nitroxin and lowest number was also observed in combination of $25 \%$ chemical fertilizer + nitroxin. [22] expressed that the largest number of branches in fennel has been obtained from $50 \%$ chemical fertilizer + biological fertilizer and this results is matched with present experiment. [23] observed that consumption of nitrogen biofertilizer in fenugreek plant increased growth and number of branches and leafs of this plant.

\subsection{Number of Pods per Plant}

The effect if phosphorus fertilizer on number of pods per plant was significant (Table 2). The largest number of pods per plant was observed in treatments including $200 \mathrm{~kg}$ per hectare triple superphosphate and biophosphor with $100 \mathrm{~kg}$ per hectare triple superphosphate and lowest number of pods per plant was belonged to control treatment (lack of using fertilizer) (Table 3). Since the number of branches per plant was large in both of these fertilizing treatments and there is a direct relation between number of pods and branches, the number pods in plant has been increased. [24] declared through an experiment that there is a positive and significant correlation between number of pods and branches per plant. Another study was conducted by [25] on peanut with the aim of substituting biofertilizer with chemical fertilizer and it was revealed that the increase in number of pods per plant was related to treatments had received $25 \%$ chemical and $75 \%$ biologic fertilizers.

The effect of nitrogen fertilizer on number of pods per plant was significant (Table 2). The largest number of pods per plant was respectively observed through using $200 \mathrm{~kg}$ per hectare urea and $150 \mathrm{~kg}$ per hectare urea with nitroxin and lowest number of pods per plant was observed in control mood (Table 3). This matter might be because of the effect of nitrogen on more vegetative growth of plant and increase in photosynthesis as well as producing more photosynthetic material so that the percent of florets loss might be reduced and number of pods per plant increased. [26] stated that application of nitrogen at flowering stage would increase number of pods per canola plant due to reduction in flowers' loss percent. [27] conducted an experiment and eventuated that nitrogen fertilizer would promote vegetative growth of plant, increase leaf area and leaf area duration in plant community. More photosynthesis material was produced in plant and the number of pods in plant of sesame was increased under the effect of the mentioned fertilizer. [28] reported that application of biologic fertilizers in sesame plant significantly increased plant height, number of branches per plant, number of pods per plant, and 1000 seed weigh, and seed yield.

\subsection{Number of Seed per Pod}

The effect of phosphate fertilizer on number of seeds per pod was significant at $1 \%$ probability level (Table 2). The largest number of seeds per pod was observed in treatment including $200 \mathrm{~kg}$ per hectare triple superphosphate and low- 
est number of pods per plant was belonged to control treatment (lack of using fertilizer) (Table 3). Phosphorus is effective factor in improvement of reproductive characteristics of plant causing to increase in number of flower, seed, and fruit [25] [26]. [15] conducted an experiment and expressed that Barvar-2 phosphate biofertilizer significantly increased number of seeds in sunflower.

The effect of nitrogen on number of seeds per pod was significant at $1 \%$ probability level (Table 2). The largest number of seeds per pod respectively obsernved through using $200 \mathrm{~kg}$ per hectare urea and $150 \mathrm{~kg}$ per hectare urea with nitroxin and lowest number of seeds per pod was observed in control mood (Table 3). [12] conducted an experiment and declared that increase in soil nitrogen prevented from plant aging, increased photosynthesis duration of plant, more photosynthetic materials transferred to pods and more number of seeds formed in pod under the effect nitrogen. [10] reported that application of chemical and biological fertilizers increased physiologic and metabolic activities in sesame accumulating more dried materials in plants and number of seeds per pod.

[22] reported that use of nitrogen biofertilizer significantly increased yield and yield components of canola.

\subsection{Seed Weight}

The effect of phosphate and nitrogen fertilizers and their mutual effects on 1000 seeds weight were not significant. It seems that 1000 seed weight is more affected by genotype; hence, fertilizing could not significantly increase 1000 seed weight. [14] conducted an experiment and reported that 1000 seed weight of sesame is affected by genetic control.

\subsection{Seed Yield}

The effect of phosphate seed yield was significant (Table 2). The most seed yield was observed in treatment including $200 \mathrm{~kg}$ per hectare triple superphosphate and biophosphate with $100 \mathrm{~kg} / \mathrm{h}^{-1}$ triple superphosphate and lowest seed yield was belonged to control treatment (lack of using fertilizer) (Table 3). Barvar-2 phosphate biofertilizer has increased seed yield with dissolution of phosphorus compounds in soil and facilitating its absorption by plant. [7] reported that use of biofertilizer fertilizer and a collection of phosphate solubilizing bacteria and biophosphorus in sesame plant would significantly increase seed yield and biologic yield as well as yield components compared to control treatment (lack of using fertilizer).

[28] [29] reported that integrated application of biological and chemical nitrogen fertilizer would increase yield and yield components of canola compared to control treatment (treated plants with nitroxin without using chemical nitrogen fertilizer). Hence, it seems that efficiency of biological fertilizers will increases at the presence of chemical fertilizer. [30] [31] came to conclusion that phosphate-solubilizing microorganisms would affect the growth of chickpea plant through producing Auxin hormone and increase growth and yield indexes.

The effect of nitrogen fertilizer on seed yield was significant (Table 2). The 
most seed yield was observed respectively in use of $200 \mathrm{~kg} / \mathrm{h}^{-1}$ urea and 150 $\mathrm{kg} / \mathrm{h}^{-1}$ urea together with nitroxin and lowest seed yield was observed in control mood (Table 3). Nitrogen chemical and biologic fertilizer has a significant effect on increase in yield components such as number of pods in plant and number of seeds in pod of plant through increasing soil fertility; hence, seed yield is also increased. [32] [33] conducted an experiment and reported that different levels of nitrogen chemical and biological fertilizer produced the highest biomass and seed yield in medicinal plant of Basil (Ocimum basilicum L.).

\subsection{Harvest Index}

The effect of phosphate on Harvest Index was significant (Table 2). Fertilizing treatments assigned to a same statistical group in terms of Harvest Index and indicated the most Harvest Index while the lowest Harvest Index was observed in control treatment (Table 3).

Phosphate fertilizer increased seed yield compared to biologic yield and Harvest Index was increased under its effect. [32] conducted a study and reported that use of phosphate solubilizing bacteria increased Harvest Index of Corn due to increasing seed yield compared to biologic yield.

Regarding nitrogen fertilizer consumption, treatment of $150 \mathrm{~kg} / \mathrm{h}^{-1}$ urea together with nitroxin included the highest Harvest Index and lowest Harvest Index was observed in control treatment (Table 3). It seems that an equivalent level of nitrogen has been used in this treatment and bio-fertilizer gradually has transferred nitrogen to plant so that exorbitance vegetative growth was prevented and Harvest Index was increased while vegetative growth has been promoted within high-amount nitrogen treatment and this has reduced Harvest Index. According [33], consumption of high amounts of nitrogen led to reduction in sesame Harvest Index.

\subsection{Seed Oil Percent}

The effect of phosphorus on seed oil was significant (Table 2). The highest seed oil percent was observed in treatments including $200 \mathrm{~kg} / \mathrm{h}^{-1}$ triple superphosphate and biophosphate together with $100 \mathrm{~kg} / \mathrm{h}^{-1}$ triple superphosphate and lowest seed oil percent was belonged to control treatment (lack of using fertilizer) (Table 3). [34] conducted an experiment and reported that phosphorus has an important affect cultivation of canola so that severe shortage of phosphor can reduce oil percent from 33 to 23 percent.

The effect of nitrogen fertilizer on oil percent was significant at $1 \%$ level (Table 2). The highest oil percent was observed in treatment including nitroxin biofertilizer with $100 \mathrm{~kg}$ per hectare urea fertilizer and the lowest oil percent was belonged to treatment with $200 \mathrm{~kg} / \mathrm{h}^{-1}$ urea chemical fertilizer (Table 3). Seemingly, seed protein percent is increased and seed oil percent is decreased with an increase in nitrogen chemical fertilizer. However, nitroxin biologic fertilizer would increase plant growth with gradual increase in nitrogen so that photosynthetic severity of plant is increased and seed oil percent is increased by its ef- 
fect. [35] has expressed that application of biologic fertilizers with a low percent of chemical fertilizers on sesame plant could significantly increase seed oil percent.

\section{Conclusion}

According to the obtained results of experiment, use of nitroxin and Barvar-2 phosphate biofertilizers with $50-70$ percent of recommended nitrogen and phosphate fertilizers can be a solution to reduce consumption of chemical fertilizers; meanwhile, biological destruction and pollution resulting from the use of these chemical inputs are prevented.

\section{References}

[1] Ajimaddin, I., Vasundhara, M., Radhakrishna, D., Biradar, S.L. and Rao, G. (2005) Integrated Nutrient Management Studies in Sweet Basil (Ocimum basilicum). Indian Perfume, 49, 95-101.

[2] Antoun, H. (2005) Field and Greenhouse Trials Performed with Phosphate Solubilizing Bacteria and Fungi. Department of Soil and Agrifood Engineering, Faculty of Agriculture and Food. Science, Canada, 8 p.

[3] Elkholy, M.A., Ashly, S.E. and Gomaa, A.M. (2005) Biofertilizer of Maize Crop and Its Impact on Yield and Grain Nutrient under Low Rates of Mineral Fertilizers. Journal of Applied Science Research, 2, 117-121.

[4] Elkramany, M.F., Bahr, A.A., Mohamed, F. and Kabesh, M. (2007) Utilization of Biofertilizers in Field Crops Production 16-Groundnut Yield, Its Components and Seeds Content as Affected by Partial Replacement of Chemical Fertilizers by Bioorganic Fertilizers. Journal of Applied Sciences Research, 3, 25-29.

[5] Esmaeli, Y. and Patwardhan, A.M. (2006) Physiological Analysis of the Growth and Development of Canola (Brassica nupus L.) under Different Chemical Fertilizer Application. Asian Journal of Plant Science, 5, 745-752. https://doi.org/10.3923/ajps.2006.745.752

[6] Fathi, G., Benisaidi, A., Siadat, A. and Ebrahimpoor, F. (2002) Effect of Different Levels of Nitrogen and Plant Density on Grain Yield of Canola in the Climatic Conditions in Khozestan Province. Journal of Agriculture Science, 35, 43-57.

[7] Fazeli, S.F., Nezami, A., Parsa, M. and Kafie, M. (2012) Evaluated of Yield and Yield Component in 43 Variety of Sesame in State of Saline. Iranian Journal of Field Crops Research, 3, 378-386.

[8] Azimzadeh, S.M. and Azimzadeh, S.J. (2013) Effect of Nitroxin Biofertilizer and Nitrogen Chemical Fertilizer on Yield and Yield Components of Rapeseed (Brassica napus L.). International Journal of Agriculture and Crop Sciences, 6, 1284-1291.

[9] Bose, T. (2003) Effect of Nitrogen, Phosphorus and Potassium on Growth, Yield and Oil Content of Mustard (Brassica juncea). www.Indianindustry.com

[10] Cooke, G.W. (2005) The Value of Fertilizer Placement. Journal of the Royal Agricultural Society of England, 118, 37-49.

[11] Daniya, E., Dadari, S.A., Ndahi, W.B., Kuchinda, N.C. and Babaji, B.A. (2013) Correlation and Path Analysis between Seed Yield and Some Weed and Quantitative Components in Two Sesame (Sesamum indicum L.) Varieties as Influenced by Seed Rate and Nitrogen Fertilizer. Journal of Biology, Agriculture and Healthcare, 3, 12-17.

[12] Darzi, M.T., Ghalavand, A. and Rjali, F. (2008) Effect of Biofertilizers on the Uptake 
of Nitrogen, Phosphorus, Potassium and Seed Yield of Fennel (Foeniculum vulgare). Journal of Research of Medicinal and Aromatic Plants, 1, 1-19.

[13] Elhabbasha, S.F., Elsalam, M.S. and Kabesh, M.O. (2007) Response of Two Sesame Varieties (Sesamum indicum L.) to Partial Replacement of Chemical Fertilizers by Bioorganic Fertilizers. Research Journal of Agriculture and Biological Sciences, 3, 563-571.

[14] Kumar, B., Pandey, P. and Maheshwari, D.K. (2009) Reducation in Dose of Chemical Fertilizers and Growth Enhancement of Seaame (Sesamum indicum L.) with Application of Rhizospheric Competent Pseudomonas Aeruginosa LES4. European Journal Agriculture Research, 26, 1-59.

[15] Lopes, A.S. (2003) Soils under Cerrado: A Success Story in Soil Management. IFAPPI Regional Conference for Latin America and the Caribbean, International Fertilizer Industry Association, Paris, 1-10.

[16] Mahfouz, S.A. and Sharaf-Eldin, M.A. (2007) Effect of Mineral vs. Biofertilizer on Growth, Yield and Essential Oil Content of Fennel (Foeniculum vulgare Mill.). International Agrophysics, 21, 361-366.

[17] Mehrabi, Z. and Ehsanzadeh, P. (2011) Evaluation of Physiological Characteristics and Yield of Sesame Cultivars under Soil Moisture Regime. Journal of Agricultural Crops, 2, 75-88.

[18] Shirani, Z. (2013) The Assessment of Groundwater Pollution in the Urban Environment. Human and Environmental Quarterly, No. 24, 85.

[19] Ghosh, D.C. and Mohiuddin, M. (2000) Response of Summer Sesame to Biofertilizer and Growth Regulator. Journal of Agricultural Science, 2, 90-98.

[20] Han, H.S., Supanjani, D. and Lee, K.D. (2006) Effect of Co-Inoculation with Phosphate and Potassium Solubilizing Bacteria on Mineral Uptake and Growth of Pepper and Cucumber. Journal of Plant Soil Environment, 3, 130-136.

[21] Jahan, M., Aryaee, M., Amiri, B. and Ehyaee, H.R. (2013) Effect of Plant Growth Promoting Rhizobacteria on Quantitative and Qualitative Characteristics of Sesame. Journal of Agricultural Ecology, 1, 1-15.

[22] Jashankar, S. and Wahab, K. (2005) Effect of Integrated Nutrient Management on the Growth, Yield Components and Yield of Sesame. Sesame and Safflower Newsletter, 20, 602-608.

[23] Karami, A., Sepehri, A., Hamzehei, J. and Salimi, G. (2011) Biological Phosphorus and Nitrogen Fertilizers Impact on the Quantity and Quality of the Herb Borage (Borago officinalis L.) under Water Stress. Journal of Plant Production Technology, 1, 37-50.

[24] Mittal, V., Sigh, O., Nayyarkaur, H. and Tewari, R. (2007) Stimulatory Effect of Phosphate Solubilizing Fangat Starins (Aspergillus awarvori and Pencillum cirtinum) on the Yield of Chickpeae (Cicer arietinum). Soil Biology and Biochemistry, 40, 718-727.

[25] Mohammad-Varzi, R., Habibi, D., Vazan, S. and Pazeki, A. (2010) Effect of Nitrogen Fertilizer and Growth Promoter on Quality of Sunflower Seeds. Journal of Crop Ecophysiology, 3, 150-160.

[26] Mousavi, A., Sani, B., Sharifi, M. and Hosseini-Nejad, Z. (2005) Effect of Phosphate Solubilizing Bacteria and Mycorrhizal Fungi on Corn Yield. Journal of Iranian Agriculture, 2, 26-36.

[27] Wu, S.C., Cao, Z.H., Li, Z.G., Cheung, K.C. and Wong, M.H. (2005) Effects of Biofertilizer Containing N-Fixer, $\mathrm{P}$ and $\mathrm{K}$ Solubilizers and AM Fungi on Maize Growth: A Greenhouse Trial. Geoderma, 125, 155-166. 
https://doi.org/10.1016/j.geoderma.2004.07.003

[28] Yasari, E., Esmaeili, A., Pirdashti, H. and Mozafari, S. (2008) Azotobacter and Azospirillum Inoculants as Biofertilizers in Canola (Brassica napus L.) Cultivation. Asian Journal of Plant Science, 7, 490-494. https://doi.org/10.3923/ajps.2008.490.494

[29] Yousef Poor, Z. and Yadavi, A.R. (2013) Effect of Biological and Chemical Fertilizers of Nitrogen and Phosphorus on Quantitative and Qualitative Yield of Sunflower. Journal of Sustainable Agricultural and production Science, 1, 95-112.

[30] Nagananda, G.S., Das, A., Bhattacharya, S. and Kalpana, T. (2010) In Vitro Studies on the Effects of Biofertilizers (Azotobacter and Rhizobium) on Seed Germination and Development of Trigonella Foenum-graecum L. Using a Novel Glass Marble Containing Liquide Medium. International Journal of Botany, 6, 394-403. https://doi.org/10.3923/ijb.2010.394.403

[31] Ozer, H. (2003) Sowing Date and Nitrogen Rate Effects on Growth, Yield and Yield Components of Two Summer Rapeseed Cultivars. European Journal of Agronomy, 19, 453-463. https://doi.org/10.1016/S1161-0301(02)00136-3

[32] Raissi, A., Galavi, M., Ramroudi, M., Mousavi, S. and Rasoulizadeh, M. (2012) Effects of Phosphate Bio-Fertilizer, Organic Manure and Chemical Fertilizers on Yield, Yield Components and Seed Capabilities of Isabgol (Plantago ovate). International Journal of Agriculture and Crop Sciences, 24, 1821-1826.

[33] Ramra, D.M., Kodandaramaiah, J. and Reddy, M.P. (2007) Effect of VAM Fungi and Bacterial Biofertilizers on Mulberry Leaf Quality and Silkworm Cocoon Charecters under Semiaride Conditions. Caspian Journal of Environmental Sciences, 2, 111-117.

[34] Saeeid-Nejad, A. and Rezvani, P. (2010) Evaluation of Biological and Chemical Fertilizers Effects on Morphological Characteristics, Yield and Yield Components of Cumin Herbal Plant. Journal of Horticultural Science, 1, 38-44.

[35] Selosse, M.A., Baudoin, E. and Vandenkoornhyse, P. (2004) Symbiotic Microorganisms, Akey for Ecological Success and Protection of Plants. Comptes Rendus Biologies, 327, 639-648. https://doi.org/10.1016/j.crvi.2003.12.008

Submit or recommend next manuscript to SCIRP and we will provide best service for you:

Accepting pre-submission inquiries through Email, Facebook, LinkedIn, Twitter, etc. A wide selection of journals (inclusive of 9 subjects, more than 200 journals)

Providing 24-hour high-quality service

User-friendly online submission system

Fair and swift peer-review system

Efficient typesetting and proofreading procedure

Display of the result of downloads and visits, as well as the number of cited articles

Maximum dissemination of your research work

Submit your manuscript at: http://papersubmission.scirp.org/

Or contact oje@scirp.org 